УДК 347.943 .1 (477)

DOI https://doi.org/10.32844/2618-1258.2019.3-1.3

ЖУШМАН М.В.

\title{
ПОКАЗАННЯ СВІДКА ЯК ЗАСІБ ДОКАЗУВАННЯ ПІД ЧАС РОЗГЛЯДУ СПРАВ ГОСПОДАРСЬКИМ СУДОМ
}

Стаття присвячена аналізу вітчизняного законодавства, що регулює інститут доказування в господарському судочинстві. Остання редакція ГПК України розширила перелік засобів доказування, додавши до нього показання свідків. Відповідно до статті 66 ГПК України свідком може бути будь-яка дієздатна фізична особа, якій відомі будь-які обставини, що стосуються справи.

Актуальність теми дослідження виходить із особливості процесу доказування в господарському судочинстві, зважаючи на те, що відносини між господарюючими суб'єктами за нормами чинного законодавства підлягають особливому документальному оформленню.

Пояснювальна записка до проекту Закону України «Про внесення змін до Господарського процесуального кодексу України, Цивільного процесуального кодексу України, Кодексу адміністративного судочинства України та інших законодавчих актів» від 23.03.2017 № 6232 містить вказівку на те, що правила господарського процесу доповнено нормами, які дозволяють використовувати показання свідків як субсидіарне джерело доказів. Отже, Закон за цією ознакою наділяє показання свідка ознаками непрямого доказу, тобто такого, який сам по собі не є достатнім для того, щоб суд вважав обставини доведеними та ухвалив судове рішення лише за наявності показань свідків та відсутності будь-яких інших доказів по справі.

Окрема увага приділяється дослідженню норм чинного вітчизняного та міжнародного законодавства, що регулюють процедуру використання такого засобу доказування, як показання свідків, та сформованій на час здійснення дослідження практиці господарських судів. У статті зроблена спроба проаналізувати практичні аспекти реалізації новел господарського процесуального законодавства щодо порядку, умов виклику та допиту свідків в судове засідання під час розгляду справи по суті.

Автором здійснюється порівняльно-правовий аналіз норм національного законодавства та зарубіжного досвіду регламентації досліджуваного питання з метою визначення шляхів вдосконалення нормативного закріплення показань свідків у Господарському процесуальному кодексі України. Окреслені перспективи подальших наукових досліджень даного інституту.

Ключові слова: виклик свідків, допит свідків, афідевіт, господарське судочинство.

The article is devoted to the analysis of the national regulatory framework governing the institution of evidence and evidence in commercial litigation. The latest edition of the Economic Procedural Code of Ukraine expanded the list of means of proof by adding testimony to it. According to Article 66 of the above Code, any capable natural person who is aware of any circumstances of the case may be a witness.

The relevance of the topic of the study comes from the peculiarities of the process of proving the court's consideration of economic cases, given that relations between economic entities are subject to special documentation under the rules of current law.

Explanatory Note to the Draft Law of Ukraine "On Amendments to the Economic Procedure Code of Ukraine, the Civil Procedure Code of Ukraine, the Code of Administrative Judiciary of Ukraine and other legislative acts” of 23.03.2017 № 6232 contains an indication that the rules of the economic process are supplemented by rules

(C) ЖУШМАН М.В. - кандидат юридичних наук, доцент кафедри цивільного процесу (Національний юридичний університет України імені Ярослава Мудрого) 
allowing use witness testimony as a subsidiary source of evidence. Therefore, the Law on this basis confers testimony on the witness with evidence of indirect evidence, that is, one which is not in itself sufficient to allow the court to consider the circumstances of the case proved and to reach a court decision only in the presence of witness testimony and in the absence of any other evidence in the case.

Particular attention is paid to a detailed study of the rules of the domestic and international legal framework governing the use of such a means of evidence as testimony of witnesses, and formed during the study of the practice of national commercial courts. The article attempts to analyze the practical aspects of the implementation of economic judiciary novelties regarding the procedure and conditions of summoning and questioning witnesses at a court hearing in the merits of the case.

The author performs a comparative legal analysis of the norms of national legislation and foreign experience of legal regulation of the investigated issue in order to determine ways to improve the standardization of the testimony of witnesses in the Economic Procedural Code of Ukraine and outline the prospects for further scientific research of this institute.

Key words: call witnesses, examine witnesses, affidavit, commercial litigation.

Вступ. Із прийняттям нової редакції Господарського процесуального кодексу від 03.10.2017 року [1] (далі - ГПК України) господарське судочинство отримало нову процесуальну фігуру, яка мала значним чином вплинути на порядок перебігу судового розгляду справи в господарському суді.

Так, до складу інших учасників процесу ввійшов свідок як дієздатна фізична особа, якій відомі будь-які обставини, що стосуються справи.

Постановка завдання. Дане дослідження ставить перед собою мету виявити позитивні та негативні аспекти введення в господарське судочинство свідка як нового учасника процесу, а також недоліки процесуального регулювання питання отримання та використання під час розгляду справи показань свідка.

Результати дослідження. Питанню доказування та ролі доказів у господарському судочинстві приділялась увага в дослідженнях І. Гуменної, Р. Марченко, Д. Притики, В. Сухоноса та інших. Проте належного висвітлення питання показання свідка як джерела отримання доказової інформації не отримало із причин відсутності на той час відповідного правового регулювання.

Процес доказування в господарському судочинстві завжди мав певні особливості, зважаючи на те, що відносини між господарюючими суб'єктами за нормами чинного законодавства підлягають особливому документальному оформленню.

Сучасна редакція ГПК України розширила перелік засобів доказування, додавши до нього показання свідків. Відповідно до статті 66 ГПК України свідком може бути будь-яка дієздатна фізична особа, якій відомі будь-які обставини, що стосуються справи.

Пояснювальна записка до проекту Закону України «Про внесення змін до Господарського процесуального кодексу України, Цивільного процесуального кодексу України, Кодексу адміністративного судочинства України та інших законодавчих актів» від 23.03.2017 № 6232 містить вказівку на те, що правила господарського процесу доповнено нормами, які дозволяють використовувати показання свідків як субсидіарне джерело доказів [2].

Отже, Закон за цією ознакою наділяє показання свідка ознаками непрямого доказу, тобто такого, який сам по собі не є достатнім для того, щоб суд вважав обставини доведеними та ухвалив судове рішення лише за наявності показань свідків та відсутності будь-яких інших доказів по справі.

Відповідно до статті 87 ГПК України показання свідка - це повідомлення про відомі йому обставини, які мають значення для справи. Не є доказом показання свідка, який не може назвати джерела своєї обізнаності щодо певної обставини, або які грунтуються на повідомленнях інших осіб.

На підставі показань свідків не можуть встановлюватися обставини (факти), які відповідно до законодавства або звичаїв ділового обороту відображаються (обліковуються) у відповідних документах. Законом можуть бути визначені інші обставини, які не можуть встановлюватися на підставі показань свідків.

ГПК України містить у собі опис умов, які попередньо мають бути дотримані у випадку, якщо учасник справи має намір викликати та допитати в судовому засіданні в якості свідка будьяку особу. 
Згідно зі ст. 88 ГПК України показання свідка викладаються ним письмово у заяві свідка. У заяві свідка зазначаються ім'я (прізвище, ім'я та по батькові), місце проживання (перебування) та місце роботи свідка, поштовий індекс, реєстраційний номер облікової картки платника податків свідка за його наявності або номер і серія паспорта, номери засобів зв'язку та адреси електронної пошти (за наявності), обставини, про які відомо свідку, джерела обізнаності свідка щодо цих обставин, а також підтвердження свідка про обізнаність із змістом закону щодо кримінальної відповідальності за надання неправдивих показань та про готовність з'явитися до суду за його викликом для підтвердження своїх свідчень.

Підпис свідка на заяві посвідчується нотаріусом. Не вимагається нотаріальне посвідчення підпису сторін, третіх осіб, їхніх представників, які дали згоду на допит їх як свідків.

Така письмова заява свідка $є$ аналогом застосовуваного в міжнародній практиці поняття афідевіту - письмового свідчення або заяви особи, що виступає в ролі свідка, яке, за неможливості (утрудненні) його особистої явки, дається під присягою і засвідчується нотаріусом або іншою уповноваженою особою.

3 огляду на глобалізацію, яка торкнулась і права, афідевіти доволі добре закріпились у правових системах, зокрема в романо-германській. В останній під цим інститутом розуміється письмове показання, що посвідчується нотаріусом або іншою уповноваженою на це посадовою особою (без складання присяги). Поширеною така практика є в корпоративних спорах: посадова особа компанії може сформувати афідевіт, в якому будуть міститися відомості про акціонерів і директорів компанії, і якщо ця інформація не зберігається в державному реєстрі, саме такий документ може підтверджувати корпоративну структуру. Також посадова особа компанії вправі сформувати афідевіт, яким підтвердити, що долучені документи є справжньою копією, наприклад, електронного листування з адреси компанії з певною особою за визначений проміжок часу. Український законодавець активно намагається пристосувати національне законодавство до європейських правових норм. Тому саме механізм афідевіту був адаптований під заяву свідка [3].

Окрім того, аналогічні до введених у нову редакцію ГПК України норм містяться також і в Арбітражному процесуальному кодексі Російської Федерації.

Таким чином, нова редакція ГПК хоча й надала нові можливості для сторін щодо подання доказів, проте знову ж звела їх до документального підтвердження - свідок має попередньо викласти свої показання в письмовій формі. При цьому дуже цікавими та дискусійними постають пов'язані із цим питання. свідка?

По-перше, коли, на якій стадії процесу сторона має право подавати в якості доказу заяву

Зі змісту статті 80 ГПК України позивач, особи, яким законом надано право звертатися до суду в інтересах інших осіб, повинні подати докази разом із поданням позовної заяви. Відповідач, третя особа, яка не заявляє самостійних вимог щодо предмета спору, повинні подати суду докази разом із поданням відзиву або письмових пояснень третьої особи.

Зазвичай позивач має вдосталь часу для підготовки та подання позовної заяви разом із належними та достатніми доказами по справи. Проте відповідач обмежений процесуальним строком на подання відзиву, до якого в якості доказів має бути долучено необхідні заяви свідків, які в такий строк може виявитись утрудненим або взагалі неможливим отримати.

За таких обставин убачається за необхідне звернутись до положень частини 4 та 5 статті 80 ГПК України, які передбачають можливість встановлення судом додаткового строку для подання доказів у випадку, якщо доказ не може бути поданий у встановлений законом строк 3 об'єктивних причин; учасник справи письмово повідомив про це суд та зазначив причини, з яких доказ не може бути подано в зазначений строк та докази, які підтверджують, що особа здійснила всі залежні від неї дії, спрямовані на отримання вказаного доказу.

Із зазначеної проблеми існує вже певна судова практика, прикладом якої може слугувати ухвала господарського суду Харківської області від 07.03.2018 по справі № 922/1581/17, якою було відмовлено в задоволенні клопотання про виклик свідків у зв'язку з тим, що відповідачем не було дотримано встановлений ГПК України порядок, не надано до відзиву на позовну заяву заяв цих осіб, а також їхньої згоди на виклик та допит; доказів дієздатності фізичних осіб, яким відомі будь-які обставини, що стосуються справи [4].

По-друге, чи може бути допитана в якості свідка особа, що не залучена до участі у справі?

Частина 1 ст.90 ГПК України закріплює право поставити в першій заяві по суті справи до десяти питань іншому учаснику справи, на які він має надати відповідь саме у формі заяви свідка. Однак при цьому незрозумілим із точки зору процесуального регулювання залишається те, на 
які ж питання має відповідати особа, яка не є учасником справи, яким чином їй такі питання поставити, або ж які саме відомості вона має право чи зобов'язана повідомити суду про обставини, що мають значення для справи в письмовій заяві свідка.

Відсутність чіткого регулювання вказаної проблеми у ГПК України дає підстави вважати, що сторона по справі в передбаченому процесуальним законом порядку (разом 3 позовом чи відзивом) має право подати письмову заяву свідка в якості письмового доказу.

На нашу думку, така особа має бути викликана та допитана в якості свідка в судовому засіданні для забезпечення всебічного та повного розгляду справи та надання можливості протилежній стороні поставити питання такому свідку та отримати відповіді, що можуть вплинути на результат розгляду справи.

По-третє, яким чином викликати в судове засідання та допитати в якості свідка особу, яка може повідомити обставини, що мають значення для справи, проте не бажає надавати заяву свідка на вимогу однієї із сторін або до неї в такої сторони немає доступу?

На жаль, така ситуація ГПК України взагалі неврегульована, адже відповідно до положень статті 89 кодексу свідок викликається судом для допиту за ініціативою суду або за клопотанням учасника справи лише в разі, якщо обставини, викладені свідком у заяві, суперечать іншим доказам або викликають у суду сумнів щодо їхнього змісту, достовірності чи повноти. Таким чином, попереднє подання до суду заяви свідка є передумовою для виклику такої особи в судове засідання.

Так, ухвалою Господарського суду Івано-Франківської області від 10.07.2018 по справі № 909/502/18 було відмовлено в задоволенні клопотання про виклик свідків, зважаючи на те, що в матеріалах справи відсутня заява ОСОБА_1, подана в порядку статті 88 Господарського процесуального кодексу України [5].

Більше того, для наступного виклику свідка в судове засідання обставини, які свідок виклав у письмовій заяві свідка, мають суперечити іншим доказам, які містяться в матеріалах справи або викликали саме у суду сумнів щодо їхнього дійсного змісту, достовірності чи повноти.

Наприклад, ухвалою Господарського суду Дніпропетровської області від 14.05.2019 по справі № 904/526/19 суд вважав за можливе викликати свідка в судове засідання для допиту, керуючись нижчевикладеним.

У вказаній справі Товариство $з$ обмеженою відповідальністю «МД СОФТКОМ» звернулось до господарського суду Дніпропетровської області з позовною заявою про зобов'язання Акціонерного товариства «Акціонерний комерційний банк «КОНКОРД» закрити поточний рахунок та перерахувати залишок грошових коштів на рахунку.

Заявлені вимоги мотивовані бездіяльністю відповідача, що полягає в незакритті рахунку позивача на вимогу останнього, що стало підставою для звернення до суду.

15.04.2019 ТОВ «МД СОФТКОМ» подало до суду заяву свідка ОСОБА_4, за змістом якої останній повідомляє суд, що усі документи, які містяться в матеріалах справи та які були надані АТ «АКБ «Конкорд» від ТОВ «МД «Софтком», що укладені (вчинені) директором ТОВ «МД «Софтком» (на реквізитах цих документів поряд, під, над підписом зазначено прізвище та ініціали ОСОБА_4), що стосуються господарської та поточної діяльності ТОВ «МД «Софтком», підписані останнім особисто та власноруч як директором ТОВ «МД «Софтком».

Відповідачем було подано клопотання про виклик свідка, оскільки, на думку останнього, обставини, викладені в заяві свідка, суперечать іншим доказам, зокрема висновку експерта, об'єктом дослідження якого були підписи ОСОБА_4 на певних документах.

Клопотання судом задоволено [6].

Існування зазначених прогалина та недостатня визначеність у ГПК України питання виклику сторонніх осіб в якості свідків зводить майже нанівець значення нового джерела доказування в господарському судочинстві, яким у деяких випадках неможливо скористатись.

За таких обставин вважаємо за необхідне (у випадку процесуальної можливості та обгрунтованості таких дій) залучати осіб, від яких $є$ намір отримати показання свідка, в якості третіх осіб, які не заявляють самостійні вимоги щодо предмета спору. Проте в будь-якому випадку питання необхідності залучення третіх осіб по справі та надання ними заяв свідка буде здійснюватися за попередньою процесуальною санкцією суду.

По-четверте, яким чином протилежній стороні задати питання свідкові, який вже надав заяву свідка за умови, що суд не вважає за необхідне викликати такого свідка в судове засідання та допитати його?

Зважаючи на те, що саме у суду мають виникнути сумніви щодо змісту, достовірності чи повноти показань свідка, що було б достатнім для виклику такого свідка для допиту в судовому 
засіданні, єдиним можливим способом процесуального впливу з боку учасника справи $є$ подання клопотання з обгрунтуванням наявних у письмовій заяві свідка суперечностей та обгрунтування і запевняння суду в недостовірності чи неповноті таких показань.

По-п’яте, які ж власне обставини не можуть встановлюватися показаннями свідка?

Згідно з положеннями статті 87 ГПК України на підставі показань свідків не можуть встановлюватися обставини (факти), які відповідно до законодавства або звичаїв ділового обороту відображаються (обліковуються) у відповідних документах. Законом можуть бути визначені інші обставини, які не можуть встановлюватися на підставі показань свідків.

Така конструкція норми дозволяє піддавати ії розширеному тлумаченню, оскільки звичаї ділового обороту (на відміну від норм законодавства), як правило, не закріплені в письмових актах.

Цивільний кодекс України закріплює поняття «звичай ділового обороту» (далі - ЦК України) [7]. Так, стаття 7 ЦК України звичаєм ділового обороту називає правило поведінки, яке не встановлене актами цивільного законодавства, але є усталеним у сфері ділового обороту. Аналогічне роз'яснення міститься і в Інформаційному листі Вищого господарського суду України № 01-8/211 від 07.04.2008 [8].

Відповідно до частини другої статті 7 ЦК України звичай, що суперечить договору або актам цивільного законодавства, у цивільних відносинах не застосовується.

Документами, що застосовуються в Україні, в яких зафіксовані звичаї ділового обороту, $є$ «Уніфіковані правила та звичаї для документарних акредитивів» в редакції 1993 р. [9], Принципи міжнародних комерційних договорів (Принципи УНІДРУА) у редакції 1994 р. [10], «Інкотермс», Офіційні правила тлумачення торговельних термінів Міжнародної торгової палати в редакції 2010 року [11].

Яким же чином суди в кожному окремому випадку визначають, чи можна встановлювати обставини по справі показаннями свідків?

Як приклад, Господарський суд Дніпропетровської області ухвалою від 09.01.2019 по справі № 904/114/19 відмовив у задоволенні клопотання про виклик свідків, мотивуючи це рішення тим, що придбання товару на ринках повинно бути підтверджено відповідними доказами (договір, чеки, квитанції, видаткові накладні тощо), тому ці обставини повинні бути підтверджені первинною документацією та не можуть бути підтверджені показаннями свідків, суд не вбачає підстав для задоволення клопотання Позивача про виклик свідків ОСОБА_3 та ОСОБА_4 [12].

Господарський суд Харківської області в ухвалі від 09.07.2019 по справі № 922/1202/19 відмовив у задоволенні клопотання про виклик свідків, посилаючись на те, що правові засади регулювання, організації державно будівельних норм України встановлюють основні положення системи стандартизації і нормування в будівництві, класифікацію нормативних документів України в галузі будівництва ДСТ України, організаційно-методичні та загально технічні вимоги до об'єктів будівництва і промислової продукції будівельного призначення, забезпечують їхнє розроблення, виробництво /виготовлення/ та експлуатацію /використання/. ДСТ затверджуються Мінбудархітектури України [13].

На противагу цьому, наприклад, ухвалою Господарського суду Дніпропетровської області від 13.08.2019 по справі №904/2899/19 судом задоволено клопотання про виклик свідків.

У цій справі Товариство з обмеженою відповідальністю «Агроспецшина» звернулося до господарського суду Дніпропетровської області з позовом про стягнення з фізичної особи - підприємця А. попередньої оплати за договором про надання послуг № 3271-С-А від 12.01.18 р. у розмірі 78600 грн., штрафних санкцій за порушення строку надання послуг за договором про надання послуг № 3271-С-А від 12.01 .18 р. в розмірі 11475 грн. 82 коп., штрафних санкцій за порушення строку повернення попередньої оплати за договором про надання послуг № 3271-С-А від 12.01.18 р. в розмірі 5862 грн. 06 коп.

Відповідач проти позову заперечував, надав заяву та просив викликати у судове засідання в якості свідка ОСОБА_1, який зможе надати свідчення щодо обсягу виконаних ним робіт для позивача ТОВ «Агроспецшина».

За даних обставин суд вважав за необхідне викликати в судове засідання для допиту у якості свідка ОСОБА_1 та зобов'язати відповідача забезпечити явку вказаного свідка до суду [14].

Однак вищезазначена ухвала не містить жодного мотивування необхідності виклику свідка для допиту в судовому засіданні, оскільки з її тексту не вбачається, яким чином долучена до матеріалів справи заява свідка суперечила іншим наявним в матеріалах справи доказам, або ж показання свідка викликали в суду сумніви щодо їхнього змісту, достовірності чи неповноти. 
Цікавим із точки зору досліджуваної проблеми є нормативне регулювання в іноземних державах участі свідка в господарському процесі та використання судом його показань в якості доказу по справі.

Так, наприклад, Арбітражний процесуальний кодекс Російської Федерації (далі - АПК РФ) також передбачає участь свідка в судовому процесі та використання показань свідка в якості доказу по справі [15]. Відповідно до положень статті 55 вказаного Кодексу, аналогічно до норм національного законодавства свідком є особа, яка володіє відомостями про фактичні обставини, що мають значення для розгляду справи.

Інтерес викликає відмінність у підході до визначення особи свідка. Норми національного законодавства, що регулюють участь свідка в господарському судочинстві, визначають, що свідком може бути лише дієздатна особа, при цьому норми Арбітражного процесуального кодексу Російської Федерації такого уточнення не містять.

Очевидним є те, що недієздатна особа не може надавати будь-яких свідчень для суду, як письмових, у формі заяви свідка, так і усних, під час допиту в залі судових засідань. Однак ГПК України також не надає будь-яких пояснень щодо необхідного ступеня такої дієздатності, що дає підстави вважати, що особа як із повною, так і з неповною, частковою чи обмеженою дієздатністю може бути свідком у господарському судочинстві.

Згідно зі статтею 67 ГПК України не можуть бути допитані в якості свідка:

1) недієздатні фізичні особи, а також особи, які перебувають на обліку чи на лікуванні у психіатричному лікувальному закладі і не здатні через свої фізичні або психічні вади правильно сприймати обставини, що мають значення для справи, або давати показання;

2) особи, які за законом зобов'язані зберігати в таємниці відомості, що були довірені їм у зв'язку з наданням професійної правничої допомоги або послуг посередництва (медіації) під час проведення позасудового врегулювання спору, - про такі відомості;

3) священнослужителі - про відомості, одержані ними на сповіді віруючих;

4) судді та присяжні - про обставини обговорення в нарадчій кімнаті питань, що виникли під час ухвалення судового рішення, або про інформацію, що стала відома судді під час врегулювання спору за його участю;

5) інші особи, які не можуть бути допитані як свідки згідно із законом чи міжнародним договором, згода на обов'язковість якого надана Верховною Радою України, без їхньої згоди.

Окрім того, особи, які мають дипломатичний імунітет, не можуть бути допитані як свідки без їхньої згоди, а представники дипломатичних представництв - без згоди дипломатичного представника.

Варто також звернути увагу на те, що існує термін процесуальної дієздатності. Чи не його мав на увазі законодавець у статті 66 ГПК України?

Повертаючись до правового регулювання інституту свідка у праві Російської Федерації, слід звернути увагу на очевидні відмінності з нормами українського законодавства.

Так, стаття 88 АПК РФ передбачає, що за клопотанням особи, що бере участь у справі, арбітражний суд викликає свідка для участі в арбітражному процесі. Особа, яка подала клопотання про виклик свідка, зобов'язана зазначити, які обставини, що мають значення для справи, може підтвердити свідок, і повідомити суду його прізвище, ім'я, по батькові та місце проживання. Арбітражний суд за своєю ініціативою може викликати у якості свідка особу, яка брала участь у складанні документа, досліджуваного судом як письмовий доказ, або у створенні або зміні предмета, досліджуваного судом як речовий доказ. Свідок повідомляє відомі йому відомості усно. За пропозицією суду свідок може викласти показання, дані усно, в письмовій формі. Показання свідка, викладені в письмовій формі, залучаються до матеріалів справи. Не є доказами відомості, що повідомляються свідком, якщо він не може вказати джерело своєї обізнаності.

Отже, письмові показання свідка в законодавстві Російської Федерації також розглядаються в якості джерела доказів, проте не $\epsilon$ передумовою для отримання та використання в якості доказу усних показань свідка.

3 одного боку, закріпивши необхідність попереднього отримання від свідка письмової заяви Господарський, процесуальний кодекс України забезпечив принцип процесуальної економії, зважаючи на формалізований (документальний) характер господарського процесу, але з іншого обмежив для учасників справи можливість використання показань свідка як джерела доказів у випадку відсутності такої заяви з певних причин.

Окремої уваги також заслуговує питання допиту сторін, третіх осіб, їхніх представників як свідків. За змістом статті 213 ГПК України вбачається, що учасник справи (його представник) 
може бути допитаний як свідок згідно із статтями 211, 212 вказаного Кодексу, якщо обставини, викладені ним у заяві свідка, суперечать іншим доказам або викликають у суду сумнів щодо їхньої достовірності.

У висновку Головного науково-експертного управління на проект Закону України «Про внесення змін до Господарського процесуального кодексу України, Цивільного процесуального кодексу України, Кодексу адміністративного судочинства України та інших законодавчих актів» (реєстр. № 6232 від 23.03.2017 р.) щодо допиту сторін, третіх осіб, їхніх представників як свідків обгрунтовано зазначалось, що в цьому випадку фактично встановлюється такий собі «подвійний» статус названих осіб, що викликає чимало непорозумінь. Зокрема, не зрозуміло чому вказані особи не можуть повідомити відомі їм факти, які мають значення для справи, залишаючись у статусі сторони чи третьої особи. Крім того, порядок допиту свідків має свої особливості, що виключає можливість допиту сторони як свідка. Зокрема, свідки, які ще не дали пояснень, не можуть перебувати у залі судового засідання під час судового розгляду. Судовий розпорядник вживає заходів, щоб свідки, яких допитали, не спілкувалися з тими, яких суд не допитав. При цьому не визначено, як передбачається унеможливити вплив тієї інформації, яка стала відома сторонам та третій особам у залі судового засідання, разі допиту їх як свідків [16].

В який же момент такі особи надають заяви свідка?

Сторони та треті особи надають до суду відповіді на поставлені їм у першій заяві по суті питання у формі заяви свідка. Однак незрозумілими залишаються обставини, за яких представник учасника справи надавав би до суду заяву свідка, за результатами оцінки якої у суду може виникнути необхідність допитати такого представника в якості свідка.

Відповідно до статті 58 ГПК України представником у суді може бути адвокат або законний представник. Під час розгляду справ у малозначних спорах (малозначні справи) представником може бути особа, яка досягла вісімнадцяти років, має цивільну процесуальну дієздатність, за винятком осіб, визначених статтею 59 зазначеного Кодексу.

Органи та інших осіб, яким законом надано право звертатися до суду в інтересах малолітніх чи неповнолітніх осіб або осіб, які визнані судом недієздатними чи дієздатність яких обмежена, представляють у суді їхні посадові особи, крім випадків, коли такі органи та особи $є$ стороною чи третьою особою у справі.

Одна й та сама особа може бути одночасно представником декількох позивачів або декількох відповідачів або декількох третіх осіб на одній стороні за умови відсутності конфлікту інтересів між ними.

Якщо щодо допиту в якості свідка законного представника особи більше (окрім зазначених) питань не виникає, то щодо допиту адвоката необхідно вказати наступне.

Відповідно до статті 1 Закону України «Про адвокатуру та адвокатську діяльність» адвокат - фізична особа, яка здійснює адвокатську діяльність на підставах та в порядку, що передбачені цим Законом [17].

Адвокатська діяльність здійснюється на принципах верховенства права, законності, незалежності, конфіденційності та уникнення конфлікту інтересів (стаття 4 Закону). Діяльність адвоката під час надання правової допомоги обмежується певними вимогами чинного законодавства та професійними обов'язками, що передбачені вищевказаним Законом.

Так, відповідно до вимог статті 21 Закону України «Про адвокатуру та адвокатську діяльність» адвокату забороняється:

1) використовувати свої права всупереч правам, свободам та законним інтересам клієнта;

2) без згоди клієнта розголошувати відомості, що становлять адвокатську таємницю, використовувати їх у своїх інтересах або інтересах третіх осіб;

3) займати у справі позицію всупереч волі клієнта, крім випадків, якщо адвокат впевнений у самообмові клієнта;

4) відмовлятися від надання правової допомоги, крім випадків, установлених законом.

Адвокат забезпечує захист персональних даних про фізичну особу, якими він володіє, відповідно до законодавства з питань захисту персональних даних.

Окрім того, чинне законодавство передбачає існування адвокатської таємниці як особливої охоронюваної законом інформації, яка не може бути розголошена за жодних обставин без згоди самого клієнта, який таку інформацію повідомив.

Адвокатською таємницею є будь-яка інформація, що стала відома адвокату, помічнику адвоката, стажисту адвоката, особі, яка перебуває у трудових відносинах з адвокатом, про клієнта, а також питання, $з$ яких клієнт (особа, якій відмовлено в укладенні договору про надання 
правової допомоги з передбачених цим Законом підстав) звертався до адвоката, адвокатського бюро, адвокатського об'єднання, зміст порад, консультацій, роз'яснень адвоката, складені ним документи, інформація, що зберігається на електронних носіях, та інші документи і відомості, одержані адвокатом під час здійснення адвокатської діяльності.

Обов'язок зберігати адвокатську таємницю поширюється на адвоката, його помічника, стажиста та осіб, які перебувають у трудових відносинах з адвокатом, адвокатським бюро, адвокатським об'єднанням, а також на особу, стосовно якої припинено або зупинено право на заняття адвокатською діяльністю. Адвокат, адвокатське бюро, адвокатське об'єднання зобов'язані забезпечити умови, що унеможливлюють доступ сторонніх осіб до адвокатської таємниці або ії розголошення.

При цьому стаття 67 ГПК України передбачає лише неможливість допиту в якості свідка особи, яка за законом зобов'язані зберігати в таємниці відомості, що були довірені їм у зв'язку з наданням професійної правничої допомоги або послуг посередництва (медіації) лише та виключно під час проведення позасудового врегулювання спору.

Тобто відомості, які стали відомі такій особі в межах розпочатого судового провадження, нібито законом не охороняються та щодо них, на перший погляд, особа може бути допитана в якості свідка.

Проте навіть у випадку, коли Господарський процесуальний кодекс України не передбачає окремої заборони для допиту в якості свідка адвоката, його помічника, стажиста та осіб, які перебувають у трудових відносинах з адвокатом, адвокатським бюро, адвокатським об'єднанням, а також особи, стосовно якої припинено або зупинено право на заняття адвокатською діяльністю, на яких поширюється принцип дії адвокатської таємниці, автор вважає за неможливе порушення такої таємниці за ухвалою суду про допит свідка.

Такий висновок випливає із системного та логічного тлумачення як норм ГПК України, так і норм Закону України «Про адвокатуру та адвокатську діяльність».

Окремим, проте не менш цікавим із точки зору автора, $є$ питання використання в якості доказу показань з чужих слів. Сьогоденна редакція ГПК України встановлює щодо цього чітке регулювання, встановивши, що показання свідка, що грунтуються на повідомленнях інших осіб, не беруться судом до уваги.

Але в цьому випадку заслуговує на увагу нормативно-правове регулювання оцінки судом доказового значення показань із чужих слів у кримінальному процесуальному законодавстві, а саме у Кримінальному процесуальному кодексі України (далі - КПК України) [18].

Відповідно до статті 97 КПК України показаннями із чужих слів є висловлювання, здійснене в усній, письмовій або іншій формі, щодо певного факту, яке грунтується на поясненні іншої особи.

Суд має право визнати допустимим доказом показання з чужих слів незалежно від можливості допитати особу, яка надала первинні пояснення, у виняткових випадках, якщо такі показання є допустимим доказом згідно з іншими правилами допустимості доказів.

Під час прийняття цього рішення суд зобов'язаний враховувати:

1) значення пояснень і показань у випадку їхньої правдивості, для з'ясування певної обставини і їхньої важливості для розуміння інших відомостей;

2) інші докази щодо питань, передбачених пунктом 1 цієї частини, які подавалися або можуть бути подані;

3) обставини надання первинних пояснень, які викликають довіру щодо їх достовірності;

4) переконливість відомостей щодо факту надання первинних пояснень; спрямовані;

5) складність спростування пояснень, показань із чужих слів для сторони, проти якої вони

6) співвідношення показань із чужих слів з інтересами особи, яка надала ці показання;

7) можливість допиту особи, яка надала первинні пояснення, або причини неможливості такого допиту.

Суд має право визнати неможливим допит особи, якщо вона:

1) відсутня під час судового засідання внаслідок смерті або через тяжку фізичну чи психічну хворобу;

2) відмовляється давати показання в судовому засіданні, не підкоряючись вимозі суду дати показання;

3) не прибуває на виклик до суду, а її місцезнаходження не було встановлено шляхом проведення необхідних заходів розшуку; 
4) перебуває за кордоном та відмовляється давати показання.

Суд може визнати доказами показання з чужих слів, якщо сторони погоджуються визнати їх доказами.

Суд має право визнати допустимим доказом показання із чужих слів, якщо підозрюваний, обвинувачений створив або сприяв створенню обставин, за яких особа не може бути допитана.

Показання із чужих слів не може бути допустимим доказом факту чи обставин, на доведення яких вони надані, якщо показання не підтверджується іншими доказами, визнаними допустимими згідно з правилами, відмінними від положень частини другої цієї статті.

Хоча такі норми надають суду права оцінювати за особистим переконанням та у виняткових випадках питання допустимості показань із чужих слів як доказу, проте автор вважає, що такі виняткові випадки мають бути передбачені також і в господарському судочинстві.

Більше того, обмеження форми показань свідка письмовою заявою свідка може навіть не виявити ситуації, за якої відомості, викладені в цій заяві, повідомляються суду насправді $з$ чужих слів, доки не забезпечена можливість з'ясування джерела цих відомостей безпосередньо у самого свідка.

3 іншої точки зору, як достатність в якості доказу лише письмової заяви свідка, так і визнання допустимими показань із чужих слів порушують принцип безпосередності судового процесу, оскільки відповідно до статті 86 ГПК України суд оцінює докази за своїм внутрішнім переконанням, що грунтується на всебічному, повному, об'єктивному та безпосередньому дослідженні наявних у справі доказів.

Висновки. Процес глобалізації призводить до поступової, якщо не уніфікації, то зближення та перехрещення не лише матеріальних, але й процесуальних норм права.

Викладення законодавцем процесуальних кодексів, в тому числі й Господарського процесуального кодексу України, в оновленій редакції та стрімкий, без перехідного періоду початок його застосування призвели до формування нової, відсутньої до цього часу судової практики.

Однією зі сфер господарського судочинства, яку було розширено та доповнено, є засоби доказування, а саме введення нового інституту показання свідків.

Намагання законодавця наблизитись до європейського прикладу застосування в судовій практиці господарського судочинства письмових показань свідка є значним кроком уперед.

Однак наявні в новому регулюванні прогалини та недоліки, на думку автора, не дадуть змоги як судовій системі, так і учасникам господарського процесу повною мірою скористатися можливостями, які мали б надаватись такими новелами.

При цьому вбачається можливим та актуальним подальше доповнення та вдосконалення нормативно-правового регулювання участі свідків у господарському судочинстві. Це можливо відносно не лише процедури отримання таких показань, але й відносно джерел отримання свідком відомостей, які він має повідомити суду, надавши, наприклад, можливість визнання допустимими показань із чужих слів у виняткових випадках, аналогічно до норм кримінального процесуального права України.

\section{Список використаних джерел:}

1.Господарський процесуальний кодекс України від 06.11.1991 p. URL : https://zakon.rada. gov.ua/laws/show/1798-12\#n2006.

2.Пояснювальна записка до проекту Закону України «Про внесення змін до Господарського процесуального кодексу України, Цивільного процесуального кодексу України, Кодексу адміністративного судочинства України та інших законодавчих актів» від 23.03.2017 № 6232. URL : http://w1.c1.rada.gov.ua/pls/zweb2/webproc4_1?pf3511=61415.

3.Авраімов А. Тi, хто бачив усе. Заккон і Бізнес. 2018. URL : https://zib.com.ua/ ua/ print/ 131658 zgidno_z_gpk_pokazannya_svidkiv_lishe_yakscho_nemae_inshih_d.html.

4.Ухвала по справі № $\overline{9} 22 / 158 \overline{1 / 17}$ / СДРСР. URL : http://www.reyestr.court.gov.ua/ Review/72821975. 75188609.

5.Ухвала по справі № 909/502/18 / ЄДРСР. URL : http://www.reyestr.court.gov.ua/Review/

6.Ухвала по справі № 904/526/19 / ЄДРСР. URL : http://www.reyestr.court.gov.ua/ Review/81723813.

7.Цивільний процесуальний кодекс України від 18.03.2004 p. URL : http://zakon2.rada.gov. ua/laws/show/1618-15/paran9179\#n9179. 
8. Про деякі питання практики застосування норм Цивільного та Господарського кодексів України: інформаційний лист Вищого господарського суду України від 07.04.2008 № 01-8/211. URL : http://zakon5.rada.gov.ua/laws/show/v_211600-08.

9. Уніфіковані правила та звичаї для документарних акредитивів від 01.01.1993. URL : http://search.ligazakon.ua/1_doc2.nsf/link1/FIN203.html.

10. Принципи міжнародних комерційних договорів (Принципи УНІДРУА) від 01.01.1994. URL : https://zakon.rada.gov.ua/laws/show/995_920.

11. «Інкотермс» Офіційні правила тлумачення торговельних термінів Міжнародної торгової палати від 01.01.2000. URL : https://zakon.rada.gov.ua/laws/show/988 007.

12. Ухвала по справі № 904/114/19 / ЄДРСР. URL : http://www.reyestr.court.gov.ua/ Review/79057573.

13. Ухвала по справі № 922/1202/19 / ЄДРСР. URL : http://www.reyestr.court.gov.ua/ Review/82887479. 83618507.

14. Ухвала по справі № 904/2899/19 / ЄДРСР. URL : http://www.reyestr.court.gov.ua/Review/

15. Арбитражный процессуальный кодекс Российской Федерации от 24.07.2002 № 95-Ф3. URL : http://www.consultant.ru/document/cons_doc_LAW_37800.

16. Висновок Головного науково-експертного управління на проект Закону України «Про внесення змін до Господарського процесуального кодексу України, Цивільного процесуального кодексу України, Кодексу адміністративного судочинства України та інших законодавчих актів» (реєстр. № 6232 від 23.03.2017 p.). URL : http://w1.c1.rada.gov.ua/pls/zweb2/ webproc4_1?pf3511=61415.

17. Закон України «Про адвокатуру та адвокатську діяльність» від 05.07.2012. URL : https:// zakon.rada.gov.ua/laws/show/5076-17.

УДК 346.13.(094)

DOI HTTPS://DOI.ORG/10.32844/2618-1258.2019.3-1.4

ОСТАПЕНКО Ю.І.

\section{КОНЦЕПЦІЯ СТАЛОГО РОЗВИТКУ: КОНЦЕПТУАЛЬНІ ПІДВАЛИНИ СУЧАСНОГО ЗАКОНОДАВСТВА}

У статті розглянуто концептуальні основи Концепції сталого розвитку та обгрунтована доцільність впровадження останніх як концептуальний базис сучасного законодавства і системи права в цілому. Досліджено загальні складові частини Концепції сталого розвитку. Встановлено, що наявний стан екологічної ситуації призводить до висновку, що Концепція сталого розвитку - це безальтернативний шлях для національного та міжнародного законодавства; та, відповідно, остання повинна бути прийнята як окремий нормативний акт як на рівні кожної окремої держави, так і на рівні міжнародних нормативів міжнародних організацій та міжнародних об'єднань. Визначено, що подальше функціонування світової господарської системи на наявних засадах може відбуватися тільки на головуючих засадах відповідної Концепції. Обгрунтовано, що основні засади Концепції сталого розвитку пов'язані з господарською діяльністю, відповідно, формують новий шлях економіко-правового механізму господарювання в розрізі стратегії сталого соціально-економічного розвитку, що у своїй основі має екологізацію, адекватну технологізацію економічної діяльності як такої та разом із цим адекватно поєднує потенціал подальшого розвитку одночасно зі збереженням навколишнього природного середовища.

(C) ОСТАПЕНКО Ю.І. - кандидат юридичних наук, асистент кафедри господарського права (Національний юридичний університет імені Ярослава Мудрого) 